\title{
The Reproductive Biology of the Caspian Green Lizard, Lacerta strigata (Sauria: Lacertidae) in Iran
}

\author{
La Biología Reproductiva de la Lagartija Verde del Mar Caspio, \\ Lacerta strigata (Sauria: Lacertidae) en Iran
}

Vida Hojati*; Seyed Mohammad Keshavarz*; Reza Behniafar* \& Abdolhossein Shiravi*

HOJATI, V.; KESHAVARZ, S. M.; BEHNIAFAR, R. \& SHIRAVI, A. The reproductive biology of the Caspian green lizard, Lacerta strigata (Sauria: Lacertidae) in Iran. Int. J. Morphol., 34(2):443-450, 2016.

SUMMARY: The Caspian Green Lizard, Lacerta strigata Eichwald, 1831, is a member of the Lacertidae family distributed in the Caspian coast of northern Iran. The specimens were found in coastal dunes, hilly areas and pastureland containing some shrubby cover. In this research, the reproductive biology of this species was studied from April 20 to September 5, 2013. Forty eight adult specimens including 24 females and 24 males were collected by hand at midday from three sampling stations (Goharbaran, Ab-Bandansar and Ab-Bandankesh) of Sari County, located in Mazandaran Province of Iran. Ovaries and testes were removed and processed for histological and morphometric studies. In females, there were $6-17$ follicles in each ovary. Totally, $6-10$ oviductal eggs were observed in mature females. The oogenic and spermatogenic cycle begins from late March, mating starts from early May, with oviposition occurring from late May to late June, with the possibility of producing a secondary clutch later in the season. In males, the mean number and mean diameter of seminiferous tubules were 86.95 and 190.4750 microns, respectively. The mean diameter of tunica albuginea, germinal layer and lumen were 18.75, 69.79 and 144.27 microns, respectively. Maximum reproductive activity occurs from early May to early June, reduces from early July and ends in August. Hence, oogenesis and spermatogenesis occurs from April through July, L. strigata follows a seasonal reproductive cycle with associated type.

KEY WORDS: Lacertidae; Caspian green lizard; Oogenesis; Spermatogenesis; Caspian coast.

\section{INTRODUCTION}

The Caspian Green Lizard, Lacerta strigata (Eichwald, 1831), is a member of the Lacertidae family distributed from southern Russia where its presence is reported in the northeastern Caucasus of Daghestan and Stavropol Territory, through eastern Georgia, Armenia, Azerbaijan and northeastern Turkey (vicinity of Mount Ararat, eastern Anatolia), and from the Caspian coast of northern Iran into southwestern Turkmenistan (Baran \& Atatür, 1998; Anderson, 1999). There is an isolated record of this lizard from Shiraz in southeastern Iran for which the identity has been confirmed (Anderson).

Until recently an isolated population existed in the area of Cape Pizunda in Abkhazia, Georgia (Tuniyev et al., 2009). It can be found in various habitats from dry grass plains to moist valleys up to $3000 \mathrm{~m}$ above sea level. Populations of this species have been found in areas with rushes, clay semi deserts, lowland, brush, shrubs, coastal dunes, hilly areas and pastureland containing some shrub by cover (Anderson).

In some places in the Caucasus the species is declining due to general habitat destruction. This species occurs in numerous protected areas. Over most of the distribution range, population of this species is common or even abundant (Tuniyev et al.). However, IUCN Listed this species as Least Concern in view of its wide distribution, presumed large population, and because it is unlikely to be declining fast enough to qualify for listing in a more threatened category (Tuniyev et al.). Younger animals and also some older females have stripes and black dots on the back. Juveniles are mostly brown with light stripes running from neck to tail and dark spots. As they mature, the males will turn almost entirely green except the hind legs and tail, which remain brown. The females tend to retain their spots and stripes to some degree as they mature, and are less bright green.

\footnotetext{
${ }^{*}$ Department of Biology, Damghan Branch, Islamic Azad University, Damghan, Iran.
} 
This research was performed in order to the study of the reproductive biology of $L$. strigata on the Caspian coast of northern Iran.

\section{MATERIAL AND METHOD}

Study Area. All specimens were collected from the three

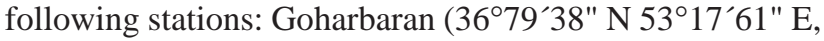
7 masl) is located in 25 kilometers north of Sari City, Ab-

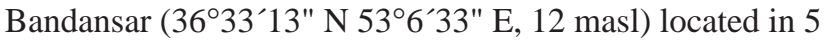
kilometers southeast of Sari City and Ab-Bandankash

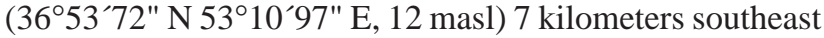
of Sari City, Mazandaran Province located in Caspian Coast of northern Iran. The climate of this area is wet and temperate. The average maximum temperature of habitat was recorded $22.5^{\circ} \mathrm{C}$ in August and the average minimum temperature was recorded $1.6^{\circ} \mathrm{C}$ in January. The average annual rainfall was recorded $728 \mathrm{~mm}$.

Sampling. Specimens hibernate from late October to late March. Sampling was conducted periodically every month during the activity period of this species from April 5 to September 5, 2013 (four specimens per month). All specimen collections were by hand, from 9 AM to 4 PM. In total, 48 adult specimens ( 24 females and 24 males) were captured. To study the clutch size, frequency of egg deposition and reproductive behaviors, some specimens were kept in terrarium.

Methods. The specimens were transferred alive to the Zoology Laboratory of Islamic Azad University, Damghan Branch and their W (Weight), SVL (South-Vent Length), LCD (Tail Length) and HL (Head Length) was measured. Then, they were anaesthetized by chloroform and anatomized. ROD (Right Ovary Diameter), LOD (Left Ovary Diameter), ROW (Right Ovary Weight), LOW (Left Ovary Weight), RFN (Right Follicles Numbers), LFN (Left Follicles Numbers), MaxRFD (Right-Follicles Maximum Diameter), MaxLFD (Left Follicles Maximum Diameter),
MinRFD (Right Follicles Minimum Diameter), MinLFD (Left Follicles Minimum Diameter), MRFD (Right Follicles Mean Diameter), MLFD (Left Follicles Mean Diameter), FLD (Follicular Layer Diameter), RTL (Right Testis Length), LTL (Left Testis Length), RTWi (Right Testis Width), LTWi (Left Testis Width), RTW (Right Testis Weight), LTW (Left Testis Weight), RTV (Right Testis Volume), LTV (Left Testis Volume), RTAD (Right Tunica Albuginea Diameter), LTAD (Left Tunica Albuginea Diameter), RSTN (Right Seminiferous Tubule Number), LSTN (Left Seminiferous Tubule Number), RSTD (Right Seminiferous Tubule Diameter), LSTD (Left Seminiferous Tubule Diameter), RGLD (Right Germinal Layer Diameter), LGLD (Left Germinal Layer Diameter), RLD (Right Lumen Diameter), LLD (Left Lumen Diameter), RSgN (Right Spermatogonia Number), LSgN (Left Spermatogonia Number), RSpN (Right Spermatocytes Number), LSpN (Left Spermatocytes Number), RStN (Right Spermatids Number), LStN (Left Spermatids Number), RSN (Right Sperms Number), LSN (Left Sperms Number), RHpL (Right Hemipenis Length), LHpL (Left Hemipenis Length), RHpW (Right Hemipenis Width) and LHpW (Left Hemipenis Width) and Gonadal Index (GI= Gonads weight/body weight '100) were measured.

Length, width and diameter measurements were done by a dial caliper with an accuracy of $0.02 \mathrm{~mm}$. Weight was measured by a scale with an accuracy of $0.001 \mathrm{~g}$. Gonads, once removed, were examined for metric and meristic characters. The number, weight and diameter of ovarian and testicular characters were studied in right and left sides, independently. After fixing the ovaries and testes in $10 \%$ formalin, tissues were dehydrated, cleared in Xylene, infiltrated and embedded with paraffin. Sections were made at 5-7 microns, deparaffinized, re-hydrated, stained (Hematoxylin and Eosin) and mounted. The sections were investigated through light microscopy at 100x and 400x magnification. Photographs were prepared by a digital camera. Data was analyzed by SPSS 18 software, one-way ANOVA and Tukey test to compare biometric data among monthly samples $(\mathrm{P}>0.05)$.

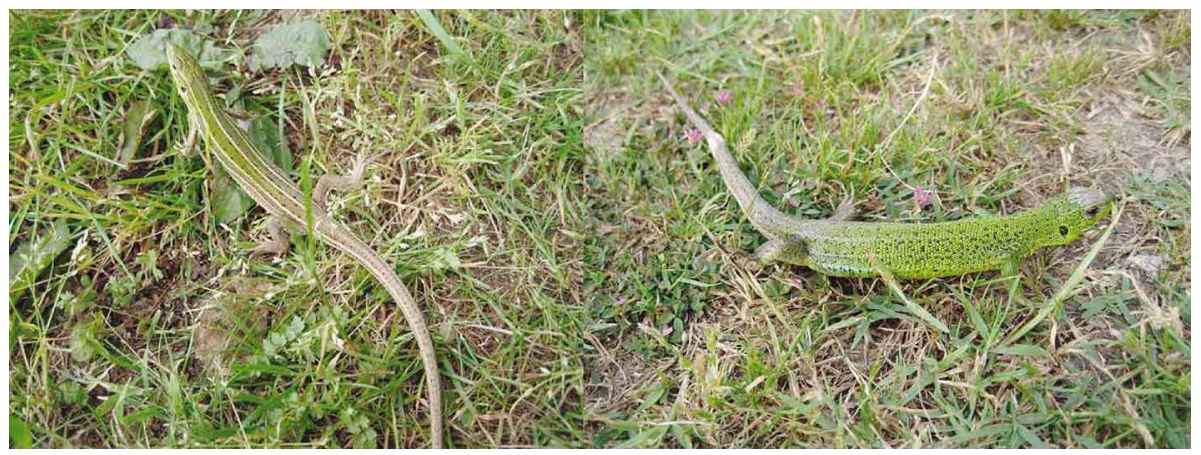

Fig. 1. Lacerta strigata, female (right) and male (left). Goharbaran, Mazandaran Province, Iran. 


\section{RESULTS}

Lacerta strigata within the study area hibernates from early October to mid-March. Emergence of the specimens occurs in early April and oogenesis begins from late March to early April. One case Mating is observed in two cases in May.

The mean SVL and LCD of females were 98.47 and $192.09 \mathrm{~mm}$ and in males were 102.34 and $186.43 \mathrm{~mm}$, respectively. The sexual dimorphism in coloration was observed in L. strigata (Fig. 2).

One pair of light orange or pink hemipenes is located at the base of the cloaca (Fig. 3). Their mean length and width of right hemipenis were 4.17 and $2.80 \mathrm{~mm}$ and those of the left side were 4.23 and $2.85 \mathrm{~mm}$, respectively. The maximum size of hemipenes was observed in June while the minimum size observed in August.

The ovaries are paired and vesicular and consist of 6-17 follicles. Three types of follicles were observed: immature, growing and mature. The small and growing

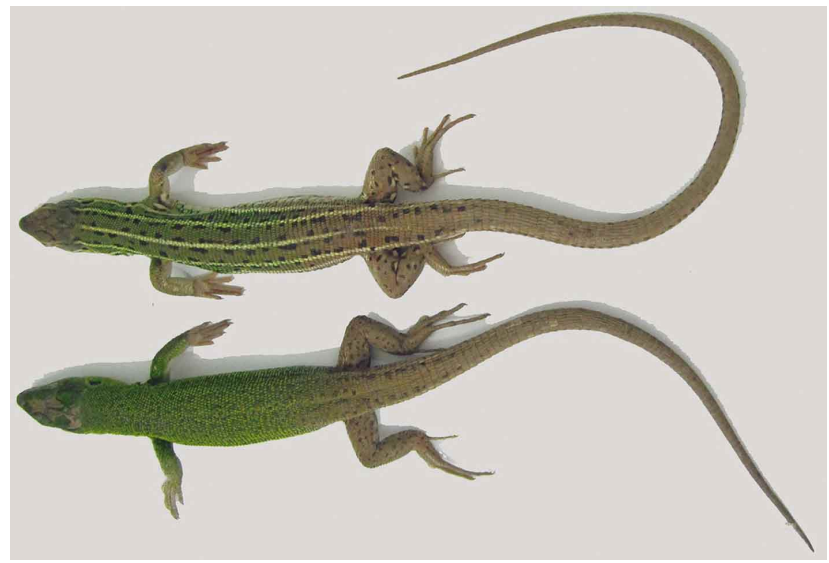

Fig. 2. Mature male (lower) and male (upper) of Lacerta strigata.

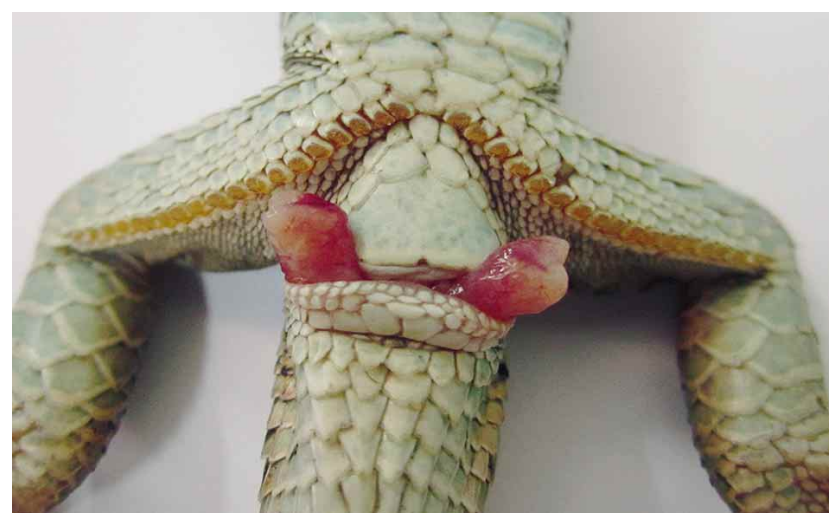

Fig. 3. Hemipenes of Lacerta strigata in early May. follicles were observed in late April with an immediate increase in their ovary size in early May and mature follicles and oviductal eggs were observed from early May to mid June. The mean diameter of ovary in May, June and September are 21.40, 29.38 and $4.87 \mathrm{~mm}$, respectively (4 specimens in each month). Female reproductive activity completely decreases in July and stops in August.

The follicular layer is multilayered and polymorphic (Fig. 4). The diameter of follicular layer is 33.13-73.88 mm. The diameter of the nucleus varies between $26-56 \mathrm{~mm}$ in immature and growing follicles. Oviductal eggs were observed between 5 May and 5 June (Figs. 5). Totally, 7-10 oviductal eggs were observed in mature females. The largest oviductal egg was $17 \times 9.62 \mathrm{~mm}(0.816 \mathrm{~g})$ and the smallest one was $12.22 \times 8.18 \mathrm{~mm}(0.481 \mathrm{~g})$. Eggs are yellowish white and oval shaped (Fig. 6). Oviposition occurs from late May to late June. The numbers of laid eggs varied 6-10 per clutches and incubated for around six to seven weeks. The diameter of largest egg was $14.83 \times 8.82 \mathrm{~mm}(0.595 \mathrm{~g})$ was laid by a female $(\mathrm{SVL}=99.96 \mathrm{~mm})$ in 19 May. The weight and SVL of the hatchling obtained in 17 July were $1.386 \mathrm{~g}$ and $32.15 \mathrm{~mm}$, respectively. Generally, the juveniles were observed from July to September (Fig. 7). Lacerta strigata evolve tail autotomy as an escape strategy. For growing, specimens shed their skin in pieces (rather than in one piece

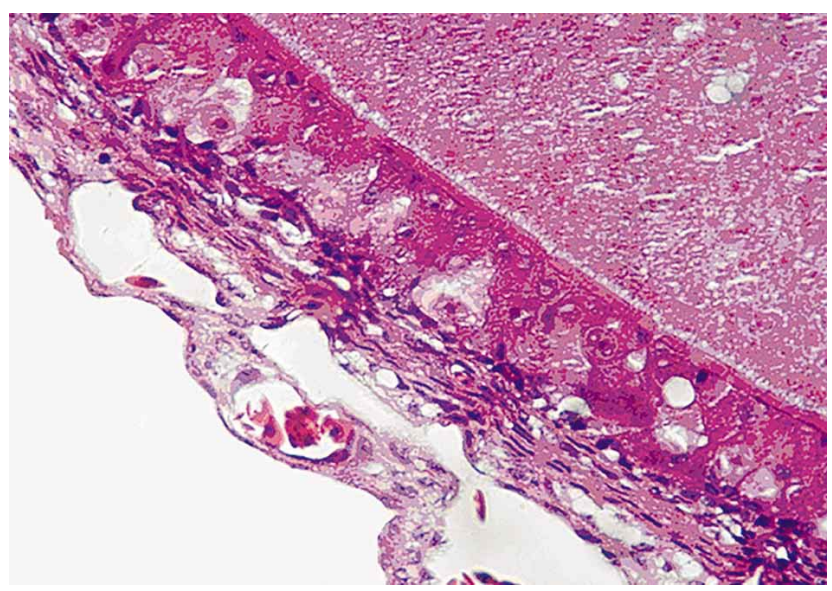

Fig. 4. The follicular layer of growing follicle in Lacerta strigata $(400 \mathrm{X})$.

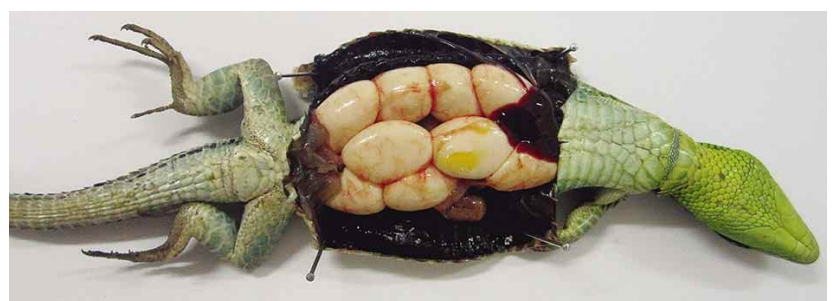

Fig. 5. Mature female of Lacerta strigata with 9 oviductal eggs on May 20. 
like a snake). After the lizard actually starts shedding, it should take no more than two weeks for all the old skin to come off. Shedding was observed from May to September (Fig. 8).

Testis were oval-shaped and yellow (Fig. 9). The mean weight, length, width and volume of right testes were $0.082 \mathrm{~g}, 7.60 \mathrm{~mm}, 4.28 \mathrm{~mm}$ and $80.28 \mathrm{~mm} 3$ and in left testes were $0.083 \mathrm{~g}, 7.34 \mathrm{~mm}, 4.28 \mathrm{~mm}$ and $77.02 \mathrm{~mm} 3$, respectively. In testes, the mean number of seminiferous tubules was 86.95 micron and the mean diameter of these was 190.47.50 micron. The mean diameter of tunica albuginea, germinal layer and lumen were 18.75, 69.79 and 144.27 microns, respectively. The mean number of spermatogonia, spermatocytes, spermatids and sperms were $147.67,125.25,89.16,152.58$ in right testes; and 104.42, 133.04, 93.45 and 152.58 in left testes, respectively. The spermatozoids were abundant in the lumen of tubules during May and June and there were no spermatozoids after early August (Fig. 10). The maximum level of sperm production was in June. The gonadal index increased from April to June

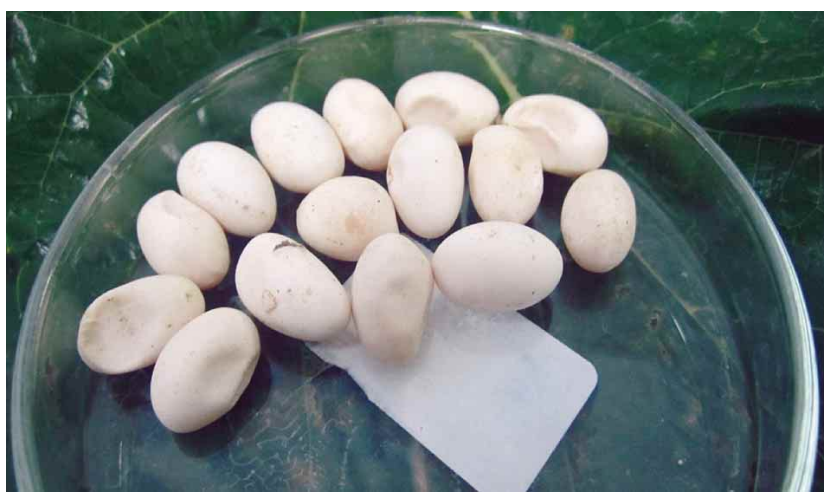

Fig. 6. The oviposited eggs of two females of Lacerta strigata in terrarium on May 20.

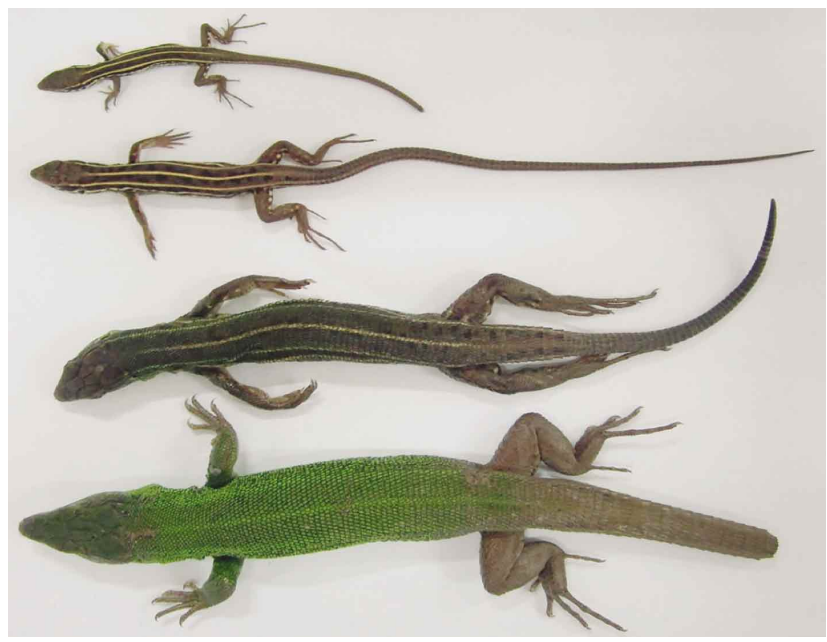

Fig. 7. The hatchling, juvenile and matures Lacerta strigata.

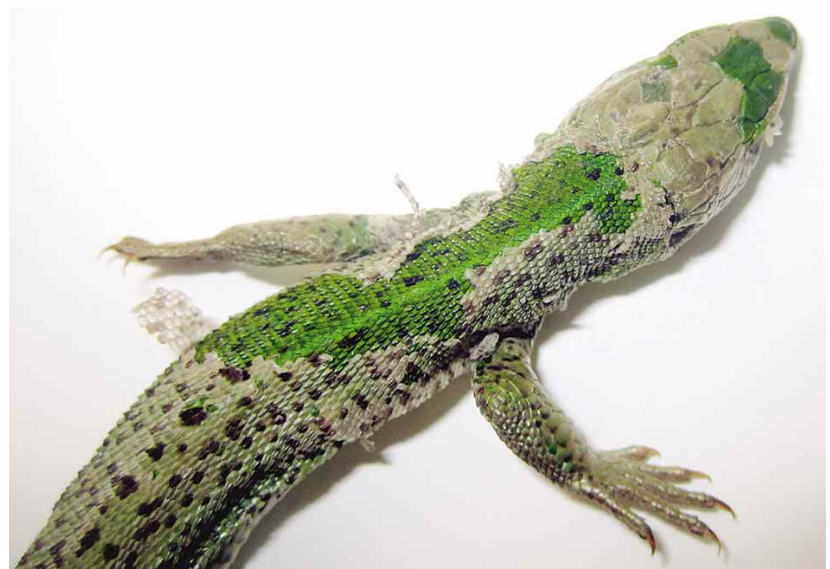

Fig. 8. The shedding skin in Lacerta strigata.

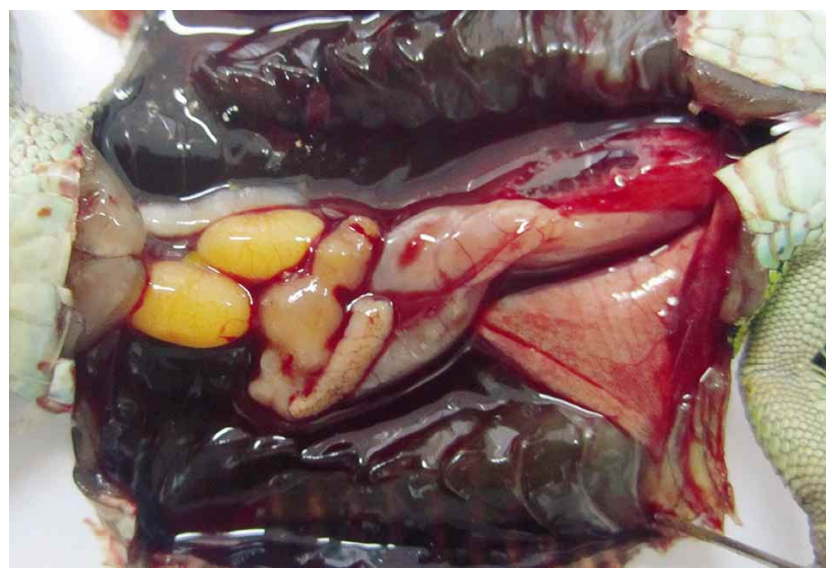

Fig. 9. Testes of Lacerta strigata in May.

and decreased from July to August. The statistical analyses of female size and ovarian characters are presented in Table I and male size, testicular and hemipenal characters are presented in Table II. In females, the body weight, left and right ovaries weight and diameter, mean diameter of left and right follicles, mean diameter of follicular layer and gonadal index have significant differences between months $(\mathrm{P}<0.05)$.

In males, the body weight, gonadal index and all testicular characters have significant differences between months $(\mathrm{P}<0.05)$. There was no significant different in body size (SVL, LCD, HL, HW) of both sexes and hemipenis size (RHpL, LHpL, RHpWi, LHpWi) between months (P $<0.05)$. The maximum activities of oogenesis and spermatogenesis take place in May and June. There were significant differences in hemipenal characters between months (Table II). No significant difference has been observed in the ovarian, testicular and hemipenal characters of the left and right side of the body (paired t-test, $\mathrm{P}>0.05$ in all cases). 


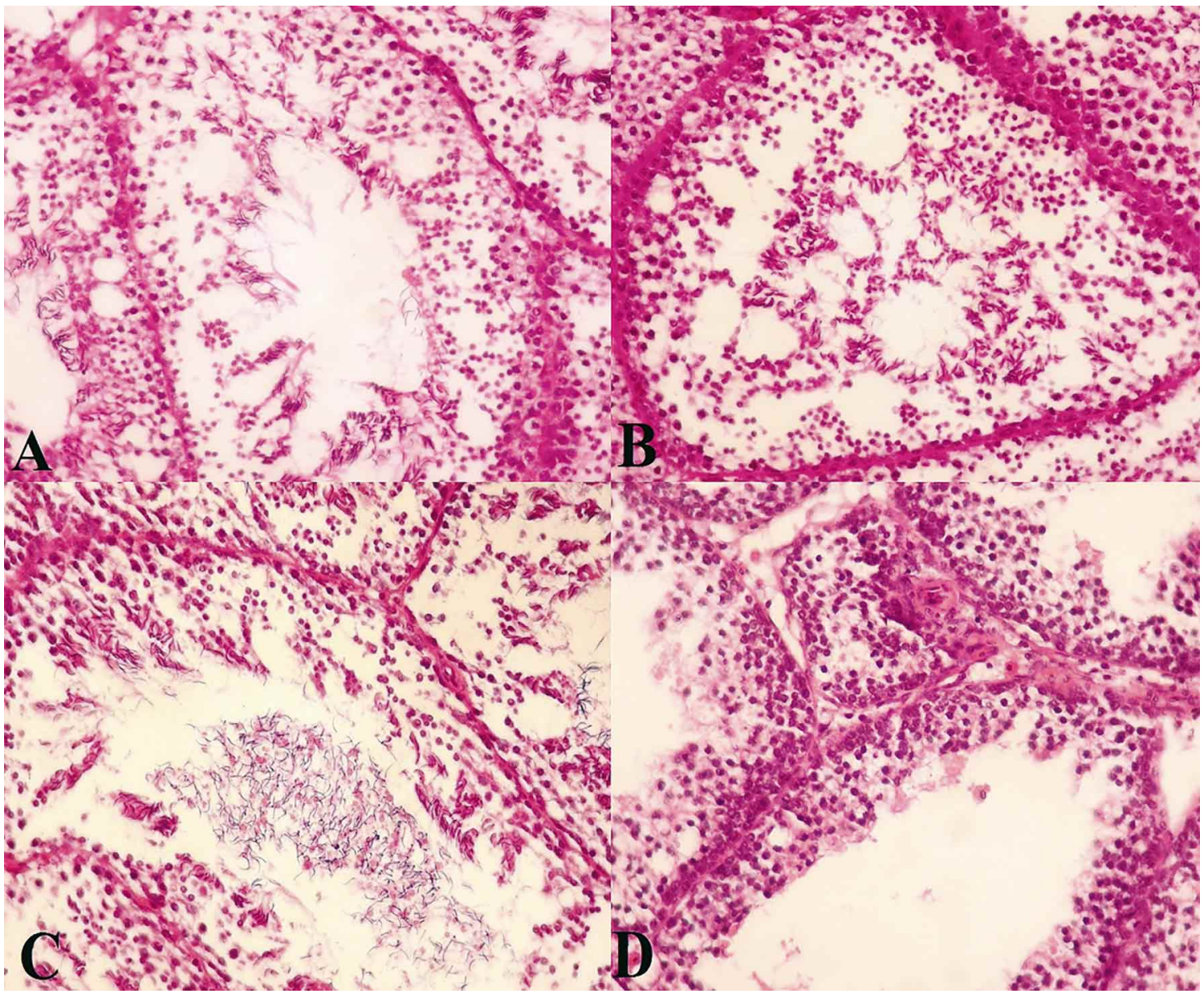

Fig. 10. The sections of seminiferous tubules of Lacerta strigata in different months (400X). A: April, B: May, C: June, and D: September.

Table I. Statistical analyses of female characters of Lacerta strigata $(\mathrm{n}=24)$

\begin{tabular}{lccccc}
\hline Characters & Minimum & Maximum & Mean \pm SE & SD & Sig. \\
\hline W $(\mathrm{g})$ & 10.56 & 31.11 & $20.60 \pm 1.24$ & 6.10 & 0.001 \\
SVL $(\mathrm{mm})$ & 86.55 & 109.44 & $98.47 \pm 1.22$ & 5.98 & 0.051 \\
LCD $(\mathrm{mm})$ & 180.17 & 227.10 & $192.09 \pm 1.78$ & 8.74 & 0.073 \\
HL $(\mathrm{mm})$ & 16.51 & 21.310 & $18.56 \pm 0.25$ & 1.24 & 0.054 \\
ROD $(\mathrm{mm})$ & 4.12 & 29.38 & $10.03 \pm 1.30$ & 6.38 & 0.004 \\
LOD $(\mathrm{mm})$ & 5.21 & 28.85 & $10.16 \pm 1.22$ & 6.01 & 0.012 \\
ROW $(\mathrm{g})$ & 0.02 & 1.32 & $0.24 \pm 0.07$ & 0.35 & 0.035 \\
LOW $(\mathrm{g})$ & 0.032 & 1.32 & $0.26 \pm 0.07$ & 0.35 & 0.070 \\
GI & 0.283 & 26.40 & $5.68 \pm 1.69$ & 8.32 & 0.018 \\
RFN & 7 & 21 & $11.37 \pm 0.63$ & 3.13 & 0.002 \\
LFN & 6 & 16 & $11.21 \pm 0.58$ & 2.84 & 0.000 \\
MaxRFD $(\mathrm{mm})$ & 1.80 & 7.52 & $4.21 \pm 0.42$ & 2.05 & 0.403 \\
MaxLFD $(\mathrm{mm})$ & 1.87 & 7.30 & $3.84 \pm 0.42$ & 2.05 & 0.136 \\
MinRFD $(\mathrm{mm})$ & 0.60 & 2.58 & $1.08 \pm 0.07$ & 0.35 & 0.407 \\
MinLFD $(\mathrm{mm})$ & 0.70 & 2.25 & $1.27 \pm 0.09$ & 0.45 & 0.001 \\
MRFD $(\mathrm{mm})$ & 0.89 & 3.88 & $2.08 \pm 0.17$ & 0.83 & 0.008 \\
MLFD $(\mathrm{mm})$ & 0.87 & 3.641 & $2.09 \pm 0.16$ & 0.82 & 0.007 \\
FLD $(\mu \mathrm{m})$ & 33.13 & 73.88 & $50.37 \pm 2.45$ & 12.03 & 0.004 \\
\hline
\end{tabular}


Table II. Descriptive statistics of male characters in Lacerta strigata $(\mathrm{n}=24)$.

\begin{tabular}{|c|c|c|c|c|c|}
\hline Characters & Minimum & Maximum & Mean \pm SE & SD & Sig. \\
\hline W (g) & 13.74 & 37.59 & $23.446 \pm 1.16$ & 5.696 & 0.005 \\
\hline SVL (mm) & 101.11 & 103.35 & $1.02 \pm 0.14$ & 0.72 & 0.982 \\
\hline $\mathrm{LCD}(\mathrm{mm})$ & 121.48 & 239.54 & $186.40 \pm 6.70$ & 32.82 & 0.324 \\
\hline HL (mm) & 22.53 & 24.78 & $23.22 \pm 0.09$ & 0.46 & 0.731 \\
\hline HW (mm) & 13.11 & 15.23 & $14.48 \pm 0.10$ & 0.51 & 0.637 \\
\hline RTW (g) & 0.020 & 0.190 & $0.082 \pm 0.008$ & 0.042 & 0.007 \\
\hline LTW (g) & 0.020 & 0.190 & $0.083 \pm 0.008$ & 0.041 & 0.003 \\
\hline RTL (mm) & 4.60 & 10.21 & $7.60 \pm 0.27$ & 1.35 & 0.002 \\
\hline LTL (mm) & 5.38 & 10.74 & $7.34 \pm 0.27$ & 1.32 & 0.001 \\
\hline RTWi (mm) & 2.77 & 5.57 & $4.28 \pm 0.15$ & 0.77 & 0.000 \\
\hline LTWi (mm) & 2.85 & 5.74 & $4.28 \pm 0.15$ & 0.73 & 0.000 \\
\hline RTV (mm3) & 18.34 & 164.74 & $80.28 \pm 8.09$ & 39.67 & 0.000 \\
\hline LTV (mm3) & 23.65 & 184.56 & $77.02 \pm 8.05$ & 39.44 & 0.000 \\
\hline GI & 0.08 & 1.20 & $0.69 \pm 0.07$ & 0.34 & 0.001 \\
\hline RTAD ( ) & 11.00 & 29.00 & $19.41 \pm 1.09$ & 5.35 & 0.000 \\
\hline LTAD ( ) & 8.00 & 29.00 & $18.08 \pm 1.14$ & 5.58 & 0.000 \\
\hline RSTN & 51.00 & 107.00 & $87.00 \pm 2.44$ & 11.96 & 0.001 \\
\hline LSTN & 61.00 & 109.00 & $86.91 \pm 2.85$ & 14.00 & 0.000 \\
\hline RSTD ( ) & 148.00 & 371.00 & $294.04 \pm 9.64$ & 47.22 & 0.000 \\
\hline $\operatorname{LSTD}()$ & 238.00 & 352.00 & $2.93 .17 \pm 6.66$ & 32.65 & 0.000 \\
\hline RGLD ( ) & 41.00 & 98.00 & $77.04 \pm 3.13$ & 15.37 & 0.000 \\
\hline LGLD (_) & 37.00 & 96.00 & $72.25 \pm 3.14$ & 15.41 & 0.000 \\
\hline $\operatorname{RLD}()$ & 97.00 & 189.00 & $141.00 \pm 5.22$ & 25.57 & 0.000 \\
\hline $\operatorname{LLD}\left(\_\right)$ & 59.00 & 132.00 & $103.04 \pm 4.78$ & 23.44 & 0.000 \\
\hline $\mathrm{RSgN}$ & 88.00 & 201.00 & $147.67 \pm 7.45$ & 36.52 & 0.000 \\
\hline $\mathrm{LSgN}$ & 58.00 & 147.00 & $104.42 \pm 6.49$ & 31.81 & 0.000 \\
\hline $\mathrm{RSpN}$ & 20.00 & 237.00 & $125.25 \pm 17.07$ & 83.65 & 0.000 \\
\hline $\mathrm{LSpN}$ & 21.00 & 329.00 & $133.04 \pm 19.84$ & 97.21 & 0.000 \\
\hline $\mathrm{RStN}$ & 0.00 & 175.00 & $89.16 \pm 12.43$ & 60.92 & 0.000 \\
\hline LStN & 0.00 & 181.00 & $93.45 \pm 12.93$ & 63.35 & 0.000 \\
\hline RSN & 0.00 & 285.00 & $150.25 \pm 20.51$ & 100.52 & 0.000 \\
\hline $\mathrm{LSN}$ & 0.00 & 301.00 & $152.58 \pm 21.26$ & 104.19 & 0.000 \\
\hline RHpL (mm) & 2.31 & 5.53 & $4.17 \pm 0.17$ & 0.85 & 0.024 \\
\hline LHpL (mm) & 2.34 & 5.53 & $4.23 \pm 0.16$ & 0.79 & 0.176 \\
\hline RHpWi (mm) & 1.17 & 3.90 & $2.80 \pm 0.16$ & 0.78 & 0.091 \\
\hline LHpWi (mm) & 1.12 & 4.19 & $2.85 \pm 0.16$ & 0.83 & 0.087 \\
\hline
\end{tabular}

\section{DISCUSSION}

The largest weight and SVL of L. strigata in this research was $31.116 \mathrm{~g}$ and $109.44 \mathrm{~mm}$, respectively. The SVL of mature females varies from $86-109 \mathrm{~mm}$. The morphology, oogenesis and folliculogenesis of the ovaries of L. strigata are related to the general Squamata pattern designated for oviparous reptiles (Moodley \& van Wyk, 2007).

The oogenesis of $L$. strigata occurred in the spring and early summer from April through late July and both ovaries are active in reproductive season.
The results show the three following oogenic cycle phases for $L$. strigata: i) Inactive phase: possessing small follicles from September to late March, ii) Vitellogenic phase: possessing growing and mature oocytes from early April to early May and iii) Oviductal egg phase: from May to late June.

The other sympatric Lacertid within the study area is the Green-bellied lizard, Darevskia chlorogaster where the largest and smallest SVL of reproductive females were recorded as $67.950 \mathrm{~mm}$ and $46.830 \mathrm{~mm}$, respectively (Nafari, 
2013). The mean diameter of follicular layer in $D$. chlorogaster varies from 30-75 microns (Nafari) and in L. strigata varies from 33-73 microns. A multilayer and polymorphic follicular layer similar to D. chlorogaster (Nafari) is reported for L. strigata and the small cells of the granulosa layer are differentiated into three distinct cell types: small, intermediate and the large pyriform cells. The maximum reproductive activity of $D$. chlorogaster is in June which follows by a reduction from July to August and finally terminates in September (Nafari). The peak of oogenic cycle of $D$. chlorogaster is in early June (Nafari) and in L. strigata is in early May. A female of $D$. chlorogaster in the same locality has laid 8 eggs in a clutch (Nafari). In present study, specimens have been laid 6-10 per clutch with the possibility of producing a secondary clutch later in the season. In a previous study, the female of $L$. strigata have been laid between six and eleven eggs in a clutch and laid two clutches each season (Baran \& Atatür).

The study of L. strigata and L. agilis in the eastern North Caucasus has been shown that the mean and maximum SVL of $L$. strigata at the first hibernation clearly decreased with altitude (Roitberg \& Smirina, 2006). Within the same localities, these parameters were consistently higher in L. agilis than in L. strigata. Between the 1st and 2nd hibernations (the period of the highest increment in SVL in all study populations), L. strigata grew faster than the syntopic L. agilis. In the lowland locality, females of both species tended to grow slower than males between the $1^{\text {st }}$ and $2^{\text {nd }}$ hibernations, while at higher elevations they exhibited lower SVL increments than the males between the $2^{\text {nd }}$ and $3^{\mathrm{d}}$ hibernations. This pattern, along with occurrence of gravid yearlings in the lowland locality (but not in the other sites), suggests an earlier onset of reproduction in the lowland populations compared to those from higher elevations. Asymptotic SVLs in the study populations tended to be larger in males than in females (Roitberg \& Smirina).

The activity period of L. agilis in in the Sierra del Cadi Eastern Pyrenees is about 4.5 months and is longer than L. strigata in present study. Vitellogenesis in females of $\mathrm{L}$. agilis is rapid about 45 days with a long period of oviductal retention (Amat et al., 2000). Clutches of L. agilis are laid at the beginning of summer but in L. strigata begins in late spring. Females deplete more fat reserves, but do so later in the season than males and they are at their lowest after egg production. In both sexes, energy resources are mobilized from the fat bodies and also from the liver and the proximal part of the tail (Amat et al.). Clutch size increases with female size but also depends on other factors (Amat et al.).
In a previous study on the spermatogenic cycle of the sympatric species, Darevskia chlorogaster, testes consisted of 74.45 seminiferous tubules on average (Choopani et al., 2014). The mean diameters of seminiferous tubules, lumen, tunica albuginea and germinal layer were $350.14,162,17.69$ and 64.10 microns, respectively. Spermatogenesis started in mid March to early April, reaching its peak in late May and early June, and ended between early to mid August (Choopani et al., 2014). The maximum level of sperm production occurred in early June. The minimum diameter, weight and volume of testes were observed in early August. Four phases were observed during the spermatogenesis of D. chlorogaster: active, transitional, inactive and regenerative (Choopani et al.).

Histological studies during the spermatogenesis of Lacerta vivipara have shown two protamines, lacertines 1 and 2, are present in spermatozoa in April and May (Martinage et al., 1996).

The effects of mammalian gonadotropins on spermatogenesis in Lacerta s. sicula during the autumn thermic refractory period induce stimulation of spermatogenesis (Angelini et al., 1978). FSH acts preferentially on the spermatogonial multiplication and on the primary spermocytes; LH acts on all the stages of spermatogenesis, but in particular on spermiohistogenesis and spermiation (Angelini et al.).

The effects of gonadotrophins are temperature dependent. LH is more capable than FSH. Testosterone does not prevent the regression of spermatogenesis due to high temperatures, while it causes a clear development of the epididymis (Angelini et al.).

Specimens of L. strigata are mature in their second year (http://reptilia.dk). Once specimens have reached a year of age they can be fairly well recognized as male or female (http://www.repticzone.com).

Under semi-natural conditions the rate of spermatogenesis in Lacerta muralis was similar to that under natural conditions which indicates that the lizards were able to maintain their body temperature at an equivalent level by behavioral temperature regulation during the greater part of their activity period (Joly \& Saint Girons, 1975).

The results of this study indicate that the reproductive cycle of $L$. strigata follows an associated reproductive cycle typical of species from temperate areas that occur during the well-defined periods in which oocytes are not found in the ovaries all year round. 


\section{ACKNOWLEDGEMENTS}

Collecting permits and legal requirements were prepared by Department of Environment of Mazandaran Province of Iran. The authors wish to thank Reza Babaei Savasari and Reza Behniafar for helping in samplings.

HOJATI, V.; KESHAVARZ, S. M.; BEHNIAFAR, R. \& SHIRAVI, A. La biologia reproductiva de la lagartija verde del mar Caspio, Lacerta strigata (Sauria: Lacertidae) en Iran. Int. J. Morphol., 34(2):443-450, 2016.

RESUMEN: La lagartija verde, Lacerta strigata Eichwald, 1831 es un miembro de la familia Lacertidae distribuido en la costa del mar Caspio en el norte de Irán. Los especímenes se encontraron en las dunas costeras, zonas de colinas y pastos que contienen algo de cubierta arbustiva. En esta investigación, la biología reproductiva de esta especie fue estudiada del 20 de abril al 5 de septiembre de 2013. Cuarenta y ocho ejemplares adultos, incluyendo 24 hembras y 24 machos fueron recogidos a mano al mediodía en tres estaciones de muestreo (Goharbaran, Ab-Bandansar y AB- Bandankesh) del condado de Sari, ubicado en la provincia Mazandaran de Irán. Los ovarios y los testículos fueron retirados y procesados para estudios histológicos y morfométricos. En las hembras, se observaron 6-17 folículos en cada ovario. En total, se encontraron 6-10 huevos en los oviductos de hembras maduras. El ciclo oogénico y la espermatogénesis comenzaron a partir de fines de marzo, el apareamiento se inició desde principios de mayo con la oviposición ocurriendo desde fines de mayo hasta fines de junio. Las hembras depositan 6-10 huevos por puesta, con la posibilidad de producir una segunda puesta más adelante en la temporada. En los machos, el número medio y el diámetro medio de los túbulos seminíferos fueron 86,95 y 190,475 micras, respectivamente. El diámetro medio de túnica albugínea, la capa germinal y lumen fueron de 18,75, 69,79 y 144,27 micras, respectivamente. La actividad reproductiva máxima se produce desde principios de mayo hasta principios de junio, se reduce desde principios de julio y termina en agosto. Por lo tanto, la ovogénesis y espermatogénesis se producen a partir de abril a julio, L. strigata sigue una temporada ciclo reproductivo con tipo asociado.

PALABRAS CLAVE: Lacertidae; Lagartija verde; Oogénesis; Espermatogenesis; Costa del mar Caspio.

\section{REFERENCES}

Amat, F.; Llorente, G. A. \& Carretero, M. A. Reproductive cycle of the sand Lizard (Lacerta agilis) in its southwestern range. Amphibia-Reptilia, 21:463-76, 2000.

Anderson, S. C. The Lizards of Iran. Ithaca, Society for the Study of Amphibians and Reptiles, 1999.

Angelini, F.; D'Uva, V.; Picariello, O. \& Ciarcia, G. Effects of mammalian gonadotrophs and testosterone on the male sexual cycle of the lizard (Lacerta s. Sicula raf.) During the autumn spermatogenesis. Monit. Zool. Ital., 12(2-3):117-41, 1978.
Baran, I. \& Atatür, M. K. Turkish Herpetofauna (Amphibians and Reptiles). Ankara, Republic of Turkey Ministry of Environment, 1998.

Choopani, A.; Hojati, V. \& Shiravi, A. The Spermatogenic Cycle of the Green-bellied Lizard, Darevskia chlorogaster (Sauria: Lacertidae) in Northern Iran. Cibtech J. Zool., 3(1):62-8, 2014.

Eichwald, E. Zoologia specialis, quam expositis animalibus tum vivis, tum fossilibus potissimuni rossiae in universum, et poloniae in specie, in usum lectionum publicarum in Universitate Caesarea Vilnensi. Zawadski, Vilnae, 1831.

Joly, J. \& Saint Girons, H. Influence of temperature on the rate of spermatogenesis, duration of spermatogenic activity and development of secondary sex characteristics in the wall-lizard, Lacerta muralis L. (Reptilia, Lacertidae). Arch. Anat. Microsc. Morphol. Exp., 64(4):317-36, 1975.

Moodley, G. K. \& van Wyk, J. H. Folliculogenesis and ovarian histology of the oviparous gecko, Hemidactylus mabouia (Sauria: Gekkonidae). Afr. J. Herpetol., 56(2):115-35, 2007.

Martinage, A.; Depeiges, A.; Wouters, D.; Morel, L. \& Sautiere, P. Spermatogenesis of the lizard Lacerta vivipara: histological studies and amino acid sequence of a protamine lacertine 1. $C$. R. Acad. Sci. III, 319(6):511-6, 1996.

Nafari, M. The study of oogenic cycle of Green-bellied lizard, Darevskia cholorogaster in Mazandaran Province. Thesis of Master Degree in Animal Biosystematics. Tehran, Islamic Azad University, Damghan Branch, Iran. 2013.

Roitberg, E. S. \& Smirina E. M. Age, body size and growth of Lacerta agilis boemica and L. strigata: a comparative study of two closely related lizard species based on skeletochronology. Herpetol. J., 16(2):133-48, 2006.

Tuniyev, B.; Ananjeva, N.; Agasyan, A.; Orlov, N.; Tuniyev, S. \& Anderson S. C. Lacerta strigata. The I. U. C. N. Red List of Threatened Species, 2009:e.T157287A5070727, 2009.

\author{
Correspondence to: \\ Dr. Vida Hojati \\ Department of Biology \\ Damghan Branch \\ Islamic Azad University \\ Damghan \\ IRAN
}

Email: vida.hojati@gmail.com

Received: 03-04-2015

Accepted: 19-01-2016 